\title{
Managerial Competencies and Competitive Advantage in Pharmaceutical Blockbusters
}

\author{
Abiodun Taiwo Olafenwa*, Ahmed Adeniyi Ojikutu**, \& Oladapo Alani Owoeye*** \\ Department of Business Administration, Babcock University, Ilishan-Remo, Nigeria \\ Corresponding author: *abiodunolafenwa@gmail.com, \\ **ojay782000@yahoo.com,***oladapo.owoeye@yahoo.com
}

\begin{abstract}
The study empirically tested the relationship between managerial competencies and competitive advantage in pharmaceutical blockbusters. According to the literature, blockbuster models and competitive strategies are significant determinants in organisational performance in the pharmaceutical industry context. However, the focus of this study is to determine whether efforts to combine managerial competence and the blockbuster model will reorient pharmaceutical companies to better competitive advantage by creating blockbuster drugs for the companies. This competitive advantage will position pharmaceutical companies in the face of increasing labour turnover, daunting economic challenges and perceived customer benefits that characterise this industry. A quantitative research design was adopted for this study, and primary data were obtained through a structured questionnaire administered to 22 managers of two major pharmaceutical firms in Lagos, Nigeria. The data obtained revealed a strong positive relationship between managerial competencies, blockbuster models and competitive advantage and three out of four hypotheses were accepted. The hypotheses were tested through Pearson's product-moment correlation and regression product of determination. Descriptive statistical tools, ANOVA and multiple linear regressions were used to assess perceptions of managerial competencies and blockbuster models on SPSS (version 23.0). Cronbach's alpha was extracted as a reliability coefficient for the data analysis $(\alpha=0.851)$. Several implications for management and policy are also discussed in light of the findings of this study. It was concluded that a deep knowledge of managerial competencies and blockbuster models are highly needed in the selected pharmaceutical companies to gain business expansion, maintain low average costs and achieve significant market share while improving on their level of service delivery and capacity to support groups or teams through training, coaching and sharing specialist knowledge. This study recommends developing strategies and deploying blockbuster models across all industries for a distinctive advantage of ineffective organisational performance and greater productivity.
\end{abstract}

Keywords: Managerial Competency, Competitive Advantage, Blockbuster models, Competitive Strategy.

How to cite:

Olafenwa, A. T., Ojikutu, A. A. \& Owoeye, O. A. (2021). Managerial competencies and competitive advantage in pharmaceutical blockbusters. International Journal of Business, Management and Economics, 2(1), 53-79. DOI : https://doi.org/10.47747/ijbmer.v2i2.223

\section{Introduction}

1.1 Background to the study

Every business organisation needs productive managers to be effective in today's stiff competition and changing business landscape (Okafor et al., 2019). Hence, a firm must discover, build, and keep skilful since managers possess diverse competencies that enable them to operate competently and concretely at different executive positions (Veliu \& 
Manxhari, 2017). When assessing the importance of managerial competencies, managers have a clear interest in determining the scale on which these competencies will direct to a sustainable competitive edge. However, many companies are poorly ready to identify, evaluate and correctly handle the strength of their competencies. For example, Gyurjyan et al. (2014). reported that healthier pharmaceutical companies tend to have stronger financial performance due to their managerial competencies. Such firms seek the introduction of blockbuster products into the markets to generate a sufficient level of profitability and hence gain a competitive advantage.

Blockbuster drugs treat a more incredible population of patients. They are thrown up by scientists either by chance or design to address a given health condition at a specified time with a capacity of attaining peak sales of $\$ 1$ billion or more (Carroll, 2009). However, the decline of blockbuster drugs due to the expiration of their patent cliff poses a severe financial challenge for many pharmaceutical companies. This situation forced pharmaceutical companies to review their business models by adopting new systems to introduce innovative generic products to the market. Hence, leaders in this industry build their market share through branded generic, more attractive priced products as the economic power of consumers in these markets is low. As a result, most users are unable to buy high priced blockbuster products. However, this generic product has drawbacks due to its low health insurance coverage; therefore, consumers are often advised by their doctors to take blockbuster drugs without any health risks. Meanwhile, most of the pharmaceutical companies have worked together to solve the problems that undermine the blockbuster model to gain a tremendous competitive advantage. Similarly, some countries like Belgium, the USA, and the Netherlands reach a high position in the international pharmaceutical industry through competitive advantage and proper pharmaceutical blockbuster drugs (Mousavi et al., 2018).

\subsection{Statement of the Research Problem}

Patent drug expirations or patentee precipice are among the main setbacks for the actualisation of blockbuster drugs (Carroll, 2009). Furthermore, the blockbuster model - a business design employed in generating blockbuster drugs has also come under pressure due to factors such as rising developmental costs, difficult-to-access drug prescribers, harsher customers (patients) and delay in bearing fruit by new scientific innovation, these limit the ability of blockbuster drugs to generate substantial profits for all actors in the pharmaceutical sector (Campbell et al., 2007). The implication is that many labour turnovers in pharmaceutical firms with more than $\$ 100$ billion drugs in sale are eroded due to expirations, thus creating a budgetary gap for concerned companies (Denoon \& Vollebregt, 2010).

Branded pharmaceutical products have specific traits capable of causing a sharp drop in market share after they go off patent. For example, an early loss of market revenue is particular if drugs are easier to imitate or are less disposed to direct prevention control (Turtle at al., 2004). Against this backdrop, leading pharmaceutical firms adopted biotechnology, sophisticated technology, and intellectual property protection right for the patent drug extension to strengthen market exclusivity of blockbuster products through their $\mathrm{R} \& \mathrm{D}$ segments and product teams (Asada, 2016). However, this also has its limitations.

Distinguished managers see patent cliffs and pressured blockbuster models as an opportunity to collaborate and reinvent drug discovery while improving on their marketing strategies to obtain sustainable competitive advantage through reliance on their managerial competencies. If a specific drug is distinguished from its alternatives in a profitable way, it will be capable of commanding an excellent price. However, if the competitive pressures are always robust, 
then the way for a pharmaceutical company to earn significant profits is to invest in costly treatment. Nevertheless, if competitive pressures are weak, then high prices for drugs may not mirror their value rather a failure of market strictness. Therefore, weak competitive forces are more injurious to consumers in the pharmaceutical sector than some others (Morton \& Boller, 2017). This study, therefore, seeks to develop sustainable competitive strategies through managerial competencies and blockbuster models to guide drug makers in generating blockbuster products to secure greater market share, which translate to a significant competitive advantage for firms.

The broad objective is to investigate the effects of managerial competencies on competitive advantage in creating blockbuster pharmaceutical products while the specific objectives are to:

1.) Examine the impact of blockbuster models on competitive advantage.

2.) Establish the connection between managerial competency' dimensions, blockbuster models and competitive advantage.

3.) Verify the impact of managerial competency' dimensions (shared vision, cooperation and empowerment) on managerial competencies.

4.) Identify the correlation between components of managerial competencies and managerial competency.

In the sequel to the above statement of the research objectives, the authors have developed the following questions to guide the feasibility of this study:

1.) What is the impact of blockbuster models on competitive advantage?

2.) What is the relationship between managerial competency' dimensions, blockbuster models and competitive advantage?

3.) What is the impact of managerial competency' dimensions on the managerial competencies of the selected pharmaceutical firms in generating blockbuster drugs?

4.) What is the correlation between managerial competency' dimensions: shared vision, cooperation and empowerment on the managerial competency of the selected pharmaceutical firms?

Essentially, this paper certainly establishes the current assemblage of knowledge by tackling the issues surrounding managerial competencies and blockbuster models in generating blockbuster drugs resulting in competitive advantage both practically and hypothetically as ascertained in the literature; presently, no study examines yet the proposed issue being floated in Nigerian pharmaceutical industry context. The research-based pharmaceutical industry makes a significant contribution to the prosperity of the world economy. For instance, DelveInsight (2019) proposed four potential blockbuster drugs to establish their position in the coming years. Reports earlier showed that these best-in-class drugs and blockbuster therapies own the competency to become market disrupters and produce a new trend of novelty research and development in the health service industry (DelveInsight, 2017). The estimated peak revenue of these drugs and their indication is presented in Table 1

A blockbuster drug is a sensitive and profitable stream, with an average per capita drug consumption in the world being 94\% (Esfandiari \& Yousefi, 2011). Moreover, it is a robust sector that has been one of the pillars of industrialised economies and is increasingly recognised as an important sector in the developing world (Mousavi et al., 2018). Hence, this study is timely and critical given the enormity of challenges confronting businesses in the current global economy as consumers demand value for any kobo spent. 
Although, pharmaceutical companies are cheered to focus on specific drugs with low replacement potential by generating blockbusters (Dolgin, 2010). However, the prevailing blockbuster model that has characterised this industry over the last few decades is increasingly out of alignment with technical prolongation and shifting social demands (Song, \& Han, 2016). Hence, this study will evaluate the current blockbuster model in two major pharmaceutical firms in Lagos to develop strategies that would increase market exclusivity of the blockbuster drugs, offering a significant revenue structure and payments for the pharmaceutical industry firms offering effective customer value.

Table 1. Blockbuster Drugs List

\begin{tabular}{|l|l|l|l|l|l|}
\hline $\begin{array}{l}\text { Name of } \\
\text { Drug }\end{array}$ & Indication & MoA & Company & $\begin{array}{l}\text { Estimated } \\
\text { Peak } \\
\text { Revenue }\end{array}$ & $\begin{array}{l}\text { Launch } \\
\text { Year }\end{array}$ \\
\hline AR 101 & Peanut allergy & $\begin{array}{l}\text { Immuno } \\
\text { modulator }\end{array}$ & $\begin{array}{l}\text { Aimmune } \\
\text { Therapeutics }\end{array}$ & \$1.66billion & 2025 \\
\hline RPC cells & $\begin{array}{l}\text { Retinitis } \\
\text { pigmentosa }\end{array}$ & $\begin{array}{l}\text { Gene } \\
\text { transferen } \\
\text { ce }\end{array}$ & ReNeuron & \$1.02billion & 2028 \\
\hline KP484 & ADHD & $\begin{array}{l}\text { Adrenergc } \\
\text { receptor } \\
\text { modulatos }\end{array}$ & Kempharm & \$1.4billion & 2021 \\
\hline Abemaciclib & $\begin{array}{l}\text { HER2+ breast } \\
\text { cancer }\end{array}$ & $\begin{array}{l}\text { CDK4/6 } \\
\text { inhibitors }\end{array}$ & Eli Lilly & $\$ 1.792$ billion & 2018 \\
\hline Emicizumab & Hemophilia A & $\begin{array}{l}\text { FVIII } \\
\text { inhibitor }\end{array}$ & Roche & \$1,788million & 2018 \\
\hline $\begin{array}{l}\text { AstraZenea } \\
\text { Acalabrutiib }\end{array}$ & B-cell cancers & $\begin{array}{l}\text { BTK } \\
\text { inhibitors }\end{array}$ & AstraZeneca & \$900million & 2018 \\
\hline
\end{tabular}

\section{Literature Review}

\subsection{Conceptual Clarification}

The concepts of managerial competency and its components, competitive advantage, together with blockbuster drugs, come under review.

\subsubsection{Managerial competencies}

Managerial competency was developed due to current and emerging business dynamism and its impact on competitive advantage observed in the performance of businesses (Boyatzis et al., 2007). The study of Veliu \& Manxhari (2017) examined the effect of managerial competencies on the business operation of SMEs in Kosovo with a view that managerial competencies are not rooted but fit the organisation's requirements. Their findings showed a significant positive relationship between managerial competencies and business performance. Managerial competencies currently play an essential role in multi-tasks enterprises. The competencies can mark the distinction between medium-level and exceptional managers. The connection between managerial competencies and sustainable competitive advantage remains a considerable outcome within organisational learning (Crook et al., 2008).

Kamukama et al. (2016), in their study, reported that managerial competencies enhanced firms' competitive advantage. Moreover, this has an indirect effect on the financial performance of commercial banks. The study emphasised the improvement of the knowledge 
and skills of managers to attain a competitive edge in the market and thus register increased profits. They stressed that managerial competencies and competitive advantage are strong predictors of the financial performance of commercial banks. Components of managerial competencies include shared vision, firm's cooperation (or firm's environment relationship quality) and empowerment (or human capital) (Sanchez, 2004; Hafeez et al., 2002; King \& Zeithamul, 2001; Hafeez \& Essmail, 2007). Ismail et al. (2010), in their study, quantitatively discovered that the components of managerial competencies, namely, human capital and relationship quality, are the idiosyncratic resources that helped SMEs leverage adequate and appropriate international relationship with foreign partners, thereby overcoming the limitation of resource scarcity while building a solid and close relationship with foreign partners for excellence and success in export markets.

In their study, Steyn \& Van-Staden (2018) segregated self-management competencies of managers within the manufacturing industry of South Africa. Their findings revealed that significant relationships exist between the components of self-administration competencies: manager's mindedness and ethical conduct, personal drive and resilience, work-life estimate, self-cognisance and self-development. These authors, therefore, suggested excellence in the application of self-management competencies for managers to improve in their business successes significantly and gained a distinct edge over their competitors.

\subsubsection{1 shared vision - a component of managerial competencies}

Shared vision, a component of managerial competencies, is defined as a firm's concern in revealing its goals, missions and objectives, policies, priorities and expectations (SantosVijande, 2005). It focuses and channels managerial competencies toward valuable accomplishments of the organisational goals. Firms with greater shared vision are likely enhanced to business excellence and success. Hence, shared vision provides a cognitive map that supplies the underlying logic for combining, deploying, and mobilising resources within the firm among the organisation's strategic business units. Many firms have witnessed this, with each separately utilising her shared vision to invent new-fangled products and services fulfilling customer and market claims (Usshawanitchakit, 2008).

\subsubsection{2 cooperation - a component of managerial competencies}

Agah et al. (2012) reported that cooperation is a crucial factor that knows when and how to draw, restate, and deploy teams to home result in an organisation. It is a collective practice toward a specific goal of frequent stake that involves interpersonal associations (Croteau et al., 2001). Cooperation acts to develop confidence, inspire eagerness, encourage others, and help settle disputes and build agreement in creating high performance (Berger \& Berger, 2004). Ekpudu et al. (2010), in their study on business and stakeholders, posited that profitable businesses required purposeful and concerted efforts in attracting and sustaining a high level of cooperation required by key stakeholders for business goals and strategies to succeed. They further re-iterated that business organisations succeed more if they are adaptive to the frequent changes in their environment by changing their structures and work processes.

\subsubsection{3 empowerment - a component of managerial competencies}

Empowerment is a process or psychical state apparent in four perceptions: significance, adequacy, self-determination, and impression (Agah et al., 2012). Specifically, this meaning concerns a feeling that one's work is personally essential (Zhang \& Bartol, 2010). Commissioning tends to enhance the significance of labour by promoting an employee recognition of the importance of contributing to overall organisational efficacy (Agah et al., 
2012). Ismail et al. (2010) reported that managerial competency significantly influenced relationship quality and partially mediated the relationship between people's empowerment and competitive advantage. This strategic move helps SMEs effectively leverage foreign partners 'competencies, particularly the knowledge of foreign markets.

\subsubsection{Competitive advantage}

Competitive advantage is an advantage that a firm has over its competitors, which rests on three critical specialities of resources and capabilities: constancy, assignable, and replicability (Sadler, 2003). To secure a competitive advantage, a transaction strategy of a firm wields the diverse materials over which it has a straightforward guide, and these materials have the capacity to produce a competitive advantage (Rijamampianina et al., 2003). Porter (1979) offer a five forces framework for analysing the competitive environment; these include the intensity of competitive rivalry, the threat of new competitors' entry, the utility of alternative solutions, bargaining power of customers, and bargaining power of suppliers. The combination of these five forces leads to a competitive advantage. When only two or three forces are favourable, competitive advantage usually cannot be persistent. However, Porter's five-force model permits firms to diagnose the prevalent condition of their assiduity in an organised way. However, the model has a boundary. Porter's model exhibits a refined, perfect market and static market composition, which is unreasonable to be established in existing dynamic markets (Wang, 2014).

Grove (1983) was acknowledged with presupposing the sixth force in the marketplace government, pressure groups, and the public. This force amplifies the concept of 'complimentary' and has led to the progress of participators and strategic alliances to counteract the competitive environment. These forces make up a company's microenvironment, which influences its ability to help its customers and earn a profit. A shift in any of these forces should be the cue of any organisation to reassess the marketplace for greater competitive advantage. All firms need to retain their managerial competencies, business model, or network, which are the factors that afford them to support a competitive advantage. Porter \& Miller research, as cited in Hamzat \& Ifekwem (2013), asserted that competitiveness is a firm's ability to produce goods and services of a broader range with the highest possible qualities and timely service delivery.

\subsubsection{Blockbuster drug: a competitive advantage}

Blockbuster drug residual potential is an essential incentive for active commercialisation. The first-mover advantage it possesses repeatedly yield a sustainable competitive edge over succeeding entrants in the pharmaceutical industry (Hollis, 2002). Hence, the issue surrounding product costing and patent expiry of blockbuster drugs must be accurately examined appropriately as early entries can be attended by the aggressive development of market prices and ponderous dropping in sales of branded drugs. Hence, a counteract or retroactive value suited for generic suppliers to establish themselves in the market at a maturity stage. Hence, the launch of blockbuster fighter brand, in response to market dynamics, is a potentially strategic option providing a portion of demand agreeably to price impressibility with a capacity to maintain higher profit margins on sales through brand popularity and reputation with the producer taking gains of already existing manufacturing infrastructure to benefit learning curve-based outlay success (Raasch, 2008).

Hamel \& Prahalad (1994) and Evans (2003) argue that knowledge, know-how, inventive properties and competencies are the main drivers of remarkable performance in the knowledge age with a capacity to increase with use. Researchers also suggest that knowledge 
has special characteristics that make it the most important and valuable resource (Murray, 2000; Teece et al., 1997; Tiwana, 2002). Moreover, it is the only resource that is difficult to imitate Tiwana (2002). Hence, managers with distinctive competencies utilise their knowledge power to drive a firm's operation in gaining superior market share amidst global competitiveness and uncertainties. Firms that employed such managers ultimately witness most of their products becoming blockbusters and thus gain sustainable competitive advantage.

\subsubsection{Relationship between dimensions of managerial competency and blockbuster products}

Several departments within a company are involved in making decisions akin to the strategic estimate of market exclusivity. However, all departments have similar comprehension or cognisance of the strategic likelihood of extending the product vitality (Dolfsma, 2011). An essential index for success within the framework of shared vision is to innovate and painstakingly control or direct the creative output. Therefore, scientists and patent lawyers need to declare and cooperate effectively to ascertain a common denominator. Pharmaceutical scientists need to have an improved conception of the patent fundamentals. They often do not realise that a proficiency they made could be a patentable subject matter in sustaining blockbuster products. A lack of cooperation between these two groups and understanding of each culture may lead to missed opportunities in terms of competitiveness that are both impending and costly to the firm development. Hence, pharmaceutical innovator company needs to consider optimal the product-related strategies being consistently supported by pricing and promotional strategy in developing a blockbuster model for a sustainable competitive advantage.

\subsection{Theoretical Review}

Competitive advantage is explained by four significant theories: market-based view, the resource-based view (RBV), institutional theory, and Porter's five forces. The notion of managerial competencies is closely related to the resource-based view of strategy. The knowledge-based view and capability-based view of strategy have also been derived from the resource-based view. For the current study, the focus is on resource-based view, marketbased view and Porter's six forces; the RBV explained managerial competencies - a driver of competitive advantage while the MBV and Porter's model explained competitive advantage.

Before the emergence of Resource-Based View (RBV), (Penrose, 1959) was the foremost scholar who recognised the critical role of resources to a firm's advantage over rivals (Sadler, 2003). She began her argument by stating that firms own diversity of productive resources with the potential to create competitive advantage through the extent that they are exploited for their potent estimable services. RBV of the firm draws attention to the firm's internal environment as a driver of competitive advantage and emphasises the resources that firms have developed to compete in the environment (Ansoff, 1965; Chandler, 1962; Hoskisson et al., 1999). Investigators supporting the RBV posit that only strategically considerable and beneficial resources and competencies should be regarded as the origin of competitive advantage (Barney, 1991). They have used terms like core competencies (Prahalad \& Hamel, 1994), distinctive competencies (Papp \& Lufmann, 1995, managerial competencies (Boyatzis et al., 2007), entrepreneurial competencies (Tehseen \& Ramayah, 2015) and strategic assets (Markides \& Williamson, 1994) to indicate strategically considerable resources and competencies, which offer a firm with an implicit competitive edge.

Competitive advantage is mainly used to explain the relative accomplishment of competitors in an available market enfold (Peteraf \& Barney, 2003). Hence, the presumption is that if 
strategic wealth is allied with loftier performance, then a competitive advantage must be originated. The resource-based view of the firm emphasised that a defensive competitive advantage stemmed from the firm's ownership of rare resources and hard to copy knowledge, skills, and competencies by competitors. Although resources are a source of a firm's facility, competence utilises resources to obtain administrative rent, which is the primary origin of achieving competitive advantage (Markhloufi \& Al-Erjal, 2017). Barney (1991), in his perspective of the RBV, stated that for resources to be strategically considerable, such should have four imputes, namely, value, rare, imperfectly imitable and non-substitutable. These resources, if valuable, enable the firm internally and externally for the successful tool of effectual strategies. If resources are rare, the firm can apply a choice strategy among its prevalent and potential competitors to originate added value. Besides, competitors cannot replicate, copy, or replace these resources for defending the advantages gained in the valuecreating strategies.

The Market Base View includes the positioning school of theories of strategy, which focused on the firm's environment and external factors (Hoskisson et al., 1999; Mintberg et al., 1998; Porter, 1980). The MBV of strategy argues that industry factors and external market orientation are the primary determinants of a firm's performance (Peteraf \& Bergen, 2003). The sources of value for the firm are embedded in the competitive situation characterising its end-product strategic position, which determines the firm's profitability and performance.

Although, it has been debated that the RBV ignores the nature of the market claim and only focuses on internal resources (Hooley et al., 1996). Maier \& Remus (2002) defined the concept of 'fit' as a balancing act between the external-oriented MBV and the internaloriented RBV. Amit \& Schoemaker (1993) pointed out the critical link between the firm's internal resources and external market conditions. Wang (2004) therefore, suggested that the link between the idiosyncratic firm and the network of association in which the firm is rooted is essential for competitive advantage.

Porter (1980) proposed the concepts of cost leadership and identification as two leading sources of competitive advantage. The argument is that a low-cost position empowers a firm to use provocative pricing and eminent sales volume, which can be attained through blockbuster products. A differentiation strategy involves creating a customer perception that a product or service is superior to other firms based on brand, quality, and performance. As a result, a premium price can be charged to customers. A focus strategy involves using either a differentiation or cost leadership strategy in a narrow market segment where most pharmaceutical companies in Nigeria operate. However, firms can auspiciously enunciate both low cost and distinguished products for separate market categories, and this can be their source of competitive advantage. Developing strategies is a core competence that differentiates one firm from another in an industry where essential resources are universal across firms. Firms must be interested in the current time profitability and profitability both in the medium and long term as their source for competitive advantage. These views require that firms layout strategies on how they will compete when their floating strategies become either disused or are imitated by rivals.

\subsection{Theoretical Framework}

Based on the review of existing literature, the authors thus anchored the study of managerial competencies and competitive advantage in pharmaceutical blockbusters on the resourcebased view (RBV), market-based view (MBV) and Porter's six forces.

\subsection{Empirical Review}


This is the review of the literature on the study. It comprises empirical review in developed countries, developing countries and Nigeria, as presented in Table 2

Table 2 Empirical Review on Managerial Competency and Competitive Advantage

\begin{tabular}{|c|c|c|c|c|c|c|}
\hline $\mathbf{S} / \mathbf{N}$ & Author(s) & Year & Objectives & Methodology & Result/Findings & Gap \\
\hline 1. & $\begin{array}{l}\text { Suarez, } \\
\text { Martelo, } \\
\text { Franco, }\end{array}$ & 2018 & $\begin{array}{l}\text { Influence } \\
\text { managerial } \\
\text { competencies on } \\
\text { organisational } \\
\text { culture of public } \\
\text { universities in } \\
\text { Colombia }\end{array}$ & $\begin{array}{lr}\text { Descriptive- } \\
\text { correlational } & \text { survey } \\
\text { research design. } 409 \\
\text { Universities } & \text { staff } \\
\text { was } & \text { surveyed. } \\
\text { Omega2 } & \text { (W2) } \\
\text { correlation } & \\
\text { technique } & \text { was } \\
\text { employed } & \text { to } \\
\text { measure the degree } \\
\text { of association or } \\
\text { relationship between } \\
\text { variables. }\end{array}$ & $\begin{array}{l}\text { The results } \\
\text { indicated that a } \\
\text { moderate } \\
\text { positive } \\
\text { association exist } \\
\text { between } \\
\text { managerial } \\
\text { competencies } \\
\text { and } \\
\text { organisational } \\
\text { culture. }\end{array}$ & $\begin{array}{l}\text { No research } \\
\text { has } \\
\text { investigated } \\
\text { the influence } \\
\text { of managerial } \\
\text { competencies } \\
\text { on the } \\
\text { organisational } \\
\text { culture of } \\
\text { public } \\
\text { universities in } \\
\text { Colombia. }\end{array}$ \\
\hline 2. & $\begin{array}{l}\text { Ochonma, } \\
\text { Nwankwor, } \\
\text { Henry-Arize, } \\
\text { Igwe, } \\
\text { Nwodoh } \\
\text { Ingwu }\end{array}$ & 2018 & $\begin{array}{l}\text { To investigate the } \\
\text { relationship } \\
\text { between managers' } \\
\text { different years of } \\
\text { experience on the } \\
\text { job and their } \\
\text { competency. }\end{array}$ & $\begin{array}{l}\text { A cross-sectional } \\
\text { research design was } \\
\text { adopted. } 104 \\
\text { management staff of } \\
25 \text { hospitals in the } \\
\text { FCT, Abuja, } \\
\text { Nigeria, } \\
\text { surveyed. The data } \\
\text { collected } \\
\text { analysed through } \\
\text { descriptive and } \\
\text { inferential statistics } \\
\text { (Kruskal-Wallis H } \\
\text { Test and Simple } \\
\text { Regression) on IBM } \\
\text { SPSS version 20. }\end{array}$ & $\begin{array}{l}\text { The results } \\
\text { showed no } \\
\text { significant } \\
\text { relationship } \\
\text { between } \\
\text { managers' level } \\
\text { of experience on } \\
\text { the job and their } \\
\text { competency } \\
\text { with } \\
\text { performance. }\end{array}$ & $\begin{array}{l}\text { No extant } \\
\text { studies have } \\
\text { investigated } \\
\text { the } \\
\text { relationship } \\
\text { between } \\
\text { managers' } \\
\text { different years } \\
\text { of experience } \\
\text { on the job and } \\
\text { their } \\
\text { competency in } \\
\text { Nigeria's } \\
\text { health sector. }\end{array}$ \\
\hline 3 & $\begin{array}{l}\text { Steyn, } \\
\text { Van Staden }\end{array}$ & 2018 & $\begin{array}{l}\text { To investigate } \\
\text { selected self- } \\
\text { management } \\
\text { competencies of } \\
\text { managers within } \\
\text { the manufacturing } \\
\text { industry of South } \\
\text { Africa. }\end{array}$ & $\begin{array}{l}\text { A quantitative } \\
\text { research design was } \\
\text { adopted. Three } \\
\text { hundred forty-three } \\
\text { top-and middle-level } \\
\text { managers from } 53 \\
\text { manufacturing } \\
\text { businesses in four } \\
\text { major cities of South } \\
\text { Africa participated } \\
\text { in the survey. Data } \\
\text { was collected } \\
\text { through descriptive } \\
\text { statistics, while } \\
\text { Pearson's product- } \\
\text { moment correlation } \\
\text { test was recruited to } \\
\text { test the hypotheses. }\end{array}$ & $\begin{array}{l}\text { The findings } \\
\text { revealed that } \\
\text { significant } \\
\text { relationships } \\
\text { exist between } \\
\text { the components } \\
\text { of their self- } \\
\text { management } \\
\text { competencies. }\end{array}$ & $\begin{array}{l}\text { No previous } \\
\text { studies } \\
\text { investigated } \\
\text { the } \\
\text { relationship } \\
\text { between } \\
\text { integrity and } \\
\text { ethical } \\
\text { conduct and } \\
\text { personal drive } \\
\text { and resilience } \\
\text { in the South- } \\
\text { Africa } \\
\text { manufacturing } \\
\text { sector. }\end{array}$ \\
\hline 4 & Velieui, & 2017 & To examine the & One hundred ninety- & findings & authors \\
\hline
\end{tabular}




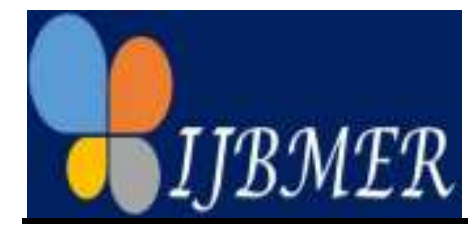

\begin{tabular}{|c|c|c|c|c|c|c|}
\hline & Manxhari & & $\begin{array}{l}\text { impact of } \\
\text { managerial } \\
\text { competencies on } \\
\text { the business } \\
\text { performance of } \\
\text { SMEs in Kosovo. }\end{array}$ & $\begin{array}{l}\text { five managers of } \\
\text { SMEs in Kosovo } \\
\text { participated in the } \\
\text { survey, but only } 110 \\
\text { responses were fit } \\
\text { for analysis. } \\
\text { Therefore, } \\
\text { descriptive } \\
\text { statistical tools, } \\
\text { principal } \\
\text { components analysis } \\
\text { (PCA), multiple } \\
\text { linear regressions } \\
\text { and varimax rotation } \\
\text { were used to assess } \\
\text { perceptions of } \\
\text { managerial on } \\
\text { competencies on } \\
\text { SPSS (version 24.0). }\end{array}$ & $\begin{array}{l}\text { revealed a } \\
\text { significant } \\
\text { positive } \\
\text { relationship } \\
\text { between } \\
\text { managerial } \\
\text { competencies } \\
\text { and business } \\
\text { performance. } \\
\text { However, } \\
\text { managerial } \\
\text { competencies } \\
\text { are not tied. } \\
\text { Hence, they } \\
\text { should match } \\
\text { the needs of the } \\
\text { organisation. }\end{array}$ & $\begin{array}{l}\text { recognised } \\
\text { recruiting } \\
\text { costs, } \\
\text { dissatisfied } \\
\text { customers and } \\
\text { missed } \\
\text { opportunities } \\
\text { in Kosovo } \\
\text { SMEs; hence, } \\
\text { they proposed } \\
\text { managerial } \\
\text { competencies } \\
\text { to fill this gap. }\end{array}$ \\
\hline 5. & $\begin{array}{l}\text { Markovic, } \\
\text { Drasković \& } \\
\text { Samardžija }\end{array}$ & 2017 & $\begin{array}{l}\text { To examine } \\
\text { competitive } \\
\text { advantage in cost- } \\
\text { sensitive European } \\
\text { glass packaging } \\
\text { industry through } \\
\text { innovative } \\
\text { outbound logistics } \\
\text { service providers. }\end{array}$ & $\begin{array}{l}\text { A qualitative } \\
\text { research design was } \\
\text { adopted to assess } \\
\text { managers of a } \\
\text { European mid-sized } \\
\text { glass packaging } \\
\text { company. The } \\
\text { authors adopted in- } \\
\text { depth structured } \\
\text { interviews of the } \\
\text { sales and logistics } \\
\text { managers. The data } \\
\text { collected } \\
\text { treated by a } \\
\text { qualitative analysis } \\
\text { of the interview } \\
\text { transcripts. }\end{array}$ & $\begin{array}{l}\text { The findings } \\
\text { revealed that } \\
\text { glass packaging } \\
\text { is unsuitable for } \\
\text { long-distance } \\
\text { transportation } \\
\text { and } \\
\text { recommended } \\
\text { close } \\
\text { cooperation } \\
\text { between the } \\
\text { stakeholders and } \\
\text { customers for } \\
\text { the effectiveness } \\
\text { of the firm's } \\
\text { outbound } \\
\text { logistics in } \\
\text { gaining a } \\
\text { sustainable } \\
\text { competitive } \\
\text { advantage. }\end{array}$ & $\begin{array}{l}\text { A stale in } \\
\text { industry } \\
\text { dynamics of } \\
\text { European } \\
\text { glass } \\
\text { packaging } \\
\text { industries } \\
\text { were } \\
\text { identified. } \\
\text { Hence, the } \\
\text { authors seek } \\
\text { new } \\
\text { cooperative } \\
\text { strategies in } \\
\text { mature } \\
\text { industries to } \\
\text { gain a } \\
\text { competitive } \\
\text { advantage. }\end{array}$ \\
\hline 6. & $\begin{array}{l}\text { Tehseen } \& \\
\text { Ramayah }\end{array}$ & 2015 & $\begin{array}{l}\text { To investigate the } \\
\text { moderating impact } \\
\text { of customer and } \\
\text { supplier } \\
\text { relationship } \\
\text { between } \\
\text { entrepreneurial } \\
\text { competencies and } \\
\text { success of } \\
\text { businesses of } \\
\text { Malaysian SMEs } \\
\text { in the } \\
\text { manufacturing } \\
\text { sector. }\end{array}$ & $\begin{array}{l}\text { This is a conceptual } \\
\text { paper to test the } \\
\text { importance of } \\
\text { entrepreneurial } \\
\text { competencies on the } \\
\text { business success of } \\
\text { SMEs. The authors } \\
\text { incorporate the } \\
\text { concept of external } \\
\text { integration of a } \\
\text { moderator between } \\
\text { the relationships of } \\
\text { the independent and } \\
\text { dependent variables, }\end{array}$ & $\begin{array}{l}\text { The author } \\
\text { hypothesised a } \\
\text { model that links } \\
\text { entrepreneurial } \\
\text { competencies, } \\
\text { external } \\
\text { integration and } \\
\text { business } \\
\text { success. }\end{array}$ & $\begin{array}{l}\text { No studies } \\
\text { have examined } \\
\text { the influence } \\
\text { of external } \\
\text { integration on } \\
\text { the } \\
\text { relationship of } \\
\text { entrepreneurial } \\
\text { competencies } \\
\text { and the } \\
\text { success of } \\
\text { Malaysian } \\
\text { SMEs } \\
\text { businesses. }\end{array}$ \\
\hline 7. & Kamukama, & 2017 & To examine the & & Managerial & No previous \\
\hline
\end{tabular}




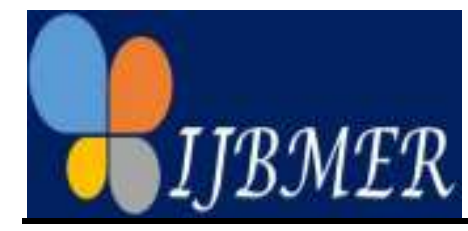

\begin{tabular}{|c|c|c|c|c|c|c|}
\hline & $\begin{array}{l}\text { Kyomuhangi, } \\
\text { Akisimire \& } \\
\text { Orobia }\end{array}$ & & $\begin{array}{l}\text { effect of } \\
\text { managerial } \\
\text { competencies on } \\
\text { business } \\
\text { performance using } \\
\text { competitive } \\
\text { advantage as a } \\
\text { moderating } \\
\text { variable. }\end{array}$ & & $\begin{array}{l}\text { competencies } \\
\text { and competitive } \\
\text { advantage are } \\
\text { strong predictors } \\
\text { of the financial } \\
\text { performance of } \\
\text { commercial } \\
\text { banks. The } \\
\text { author also } \\
\text { discovered that } \\
\text { managerial } \\
\text { competencies } \\
\text { enhanced a } \\
\text { firm's } \\
\text { competitive } \\
\text { advantage. }\end{array}$ & $\begin{array}{l}\text { studies } \\
\text { investigated } \\
\text { the effect of } \\
\text { managerial } \\
\text { competencies } \\
\text { on business } \\
\text { performance } \\
\text { using } \\
\text { competitive } \\
\text { advantage as a } \\
\text { moderator in } \\
\text { commercial } \\
\text { banks. }\end{array}$ \\
\hline 8. & $\begin{array}{l}\text { Makhloufi \& } \\
\text { Al-Erjal }\end{array}$ & 2017 & $\begin{array}{l}\text { To determine the } \\
\text { relationship } \\
\text { between furniture } \\
\text { firm's core } \\
\text { competencies and } \\
\text { the achievement of } \\
\text { SMEs in achieving } \\
\text { sustainable } \\
\text { competitive } \\
\text { advantage. }\end{array}$ & $\begin{array}{l}\text { This is theoretical } \\
\text { research to test the } \\
\text { impact of core } \\
\text { competencies on the } \\
\text { sustainable } \\
\text { competitive } \\
\text { advantage of } \\
\text { Malaysian's SME } \\
\text { furniture industry. }\end{array}$ & $\begin{array}{l}\text { The authors } \\
\text { confirm the } \\
\text { potentials of the } \\
\text { dimensions of } \\
\text { core } \\
\text { competencies in } \\
\text { yielding } \\
\text { sustainable } \\
\text { competitive } \\
\text { advantage. }\end{array}$ & $\begin{array}{l}\text { There is little } \\
\text { research } \\
\text { tackling the } \\
\text { core } \\
\text { competencies } \\
\text { learning area } \\
\text { in the SMEs } \\
\text { from the } \\
\text { managerial } \\
\text { and } \\
\text { operational } \\
\text { scene. }\end{array}$ \\
\hline 9. & $\begin{array}{l}\text { Wirda, } \\
\text { Elfindri } \\
\text { Rivai }\end{array}$ & 2019 & $\begin{array}{l}\text { To find the } \\
\text { influence } \\
\text { entrepreneurial of } \\
\text { competency on } \\
\text { business } \\
\text { performance and } \\
\text { competitive } \\
\text { advantage of } \\
\text { creative industries } \\
\text { in Indonesia. }\end{array}$ & $\begin{array}{l}\text { Two hundred } \\
\text { thirteen managers of } \\
\text { the creative industry } \\
\text { in the craft sector } \\
\text { were sampled for } \\
\text { this study. The } \\
\text { sampling technique } \\
\text { used was sampling } \\
\text { area. Data were } \\
\text { collected through a } \\
\text { questionnaire and } \\
\text { analysed by } \\
\text { structural equation } \\
\text { modelling (SEM) } \\
\text { using aMOS } \\
\text { software. }\end{array}$ & $\begin{array}{l}\text { The results } \\
\text { showed that } \\
\text { entrepreneurial } \\
\text { competency } \\
\text { positively and } \\
\text { significantly } \\
\text { affects } \\
\text { competitive } \\
\text { advantage in the } \\
\text { West Sumatra } \\
\text { creative } \\
\text { industry. }\end{array}$ & $\begin{array}{l}\text { No research } \\
\text { has examined } \\
\text { the mediating } \\
\text { effect of } \\
\text { competitive } \\
\text { advantage } \\
\text { between } \\
\text { entrepreneurial } \\
\text { competency } \\
\text { and } \\
\text { performance } \\
\text { in Indonesia. }\end{array}$ \\
\hline
\end{tabular}

\subsection{Empirical Framework}

Based on the review of the existing literature, the author found out that the findings of the scholars presented in the empirical literature apply to the study under review.

\subsection{Conceptual Framework}

The above survey of literary works on pertinent theories and fundamental framework reveals a practicable relationship between managerial competencies and competitive advantage. Therefore, the following conceptual construct was generated after considering current 
literature to diagnose the research questions. The construct reveals the linkage between the independent variables: dimensions of managerial competencies and blockbuster models and the dependent variable: competitive advantage (blockbuster products). The research seeks to empirically test the relationship between managerial competencies and competitive advantage in organisational performance.

\section{7 Research Hypotheses}

The research hypotheses are:

$\mathrm{H}_{\mathrm{o}} 1$ : Blockbuster models have a significant impact on the competitive advantage of selected pharmaceutical firms.

$\mathrm{H}_{\mathrm{o}}$ 2: Managerial competency' dimensions and blockbuster models have a significant impact on the competitive advantage of selected pharmaceutical firms.

$\mathrm{H}_{\mathrm{o}}$ 3: Managerial competency' dimensions have a significant impact on the managerial competencies of the selected pharmaceutical firms.

$\mathrm{H}_{0} 4$ : Shared vision, cooperation, and empowerment have a significant correlation with managerial competencies of the selected pharmaceutical firms

2.8 Researchers' Model 2020

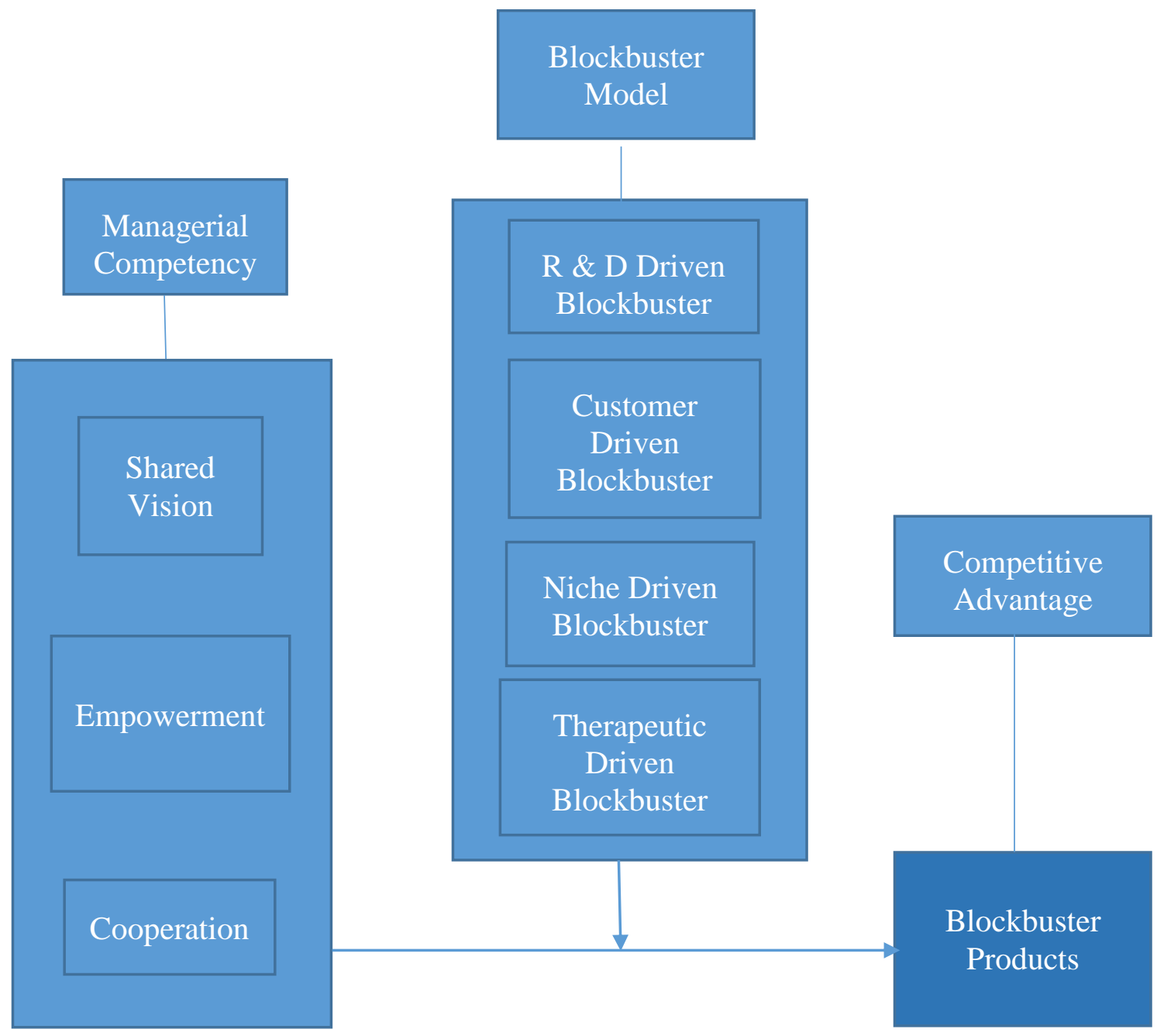

Figure 1 The Conceptual Model 


\section{Research Method}

\subsection{Area of Study}

The area of the study is Lagos State, situated in southwest Nigeria. It covers a total area of 3,577 sq. $\mathrm{km}$, the smallest of Nigerian states. However, it is the second-most populous state and arguably the most economically important country and its largest urban area.

\subsection{Research Design}

Research design means the structuring of investigation aimed at identifying variables and their relationships to one another. Therefore, a quantitative research approach is adopted for this study. The quantitative method followed a descriptive-analytical approach and field approach. The descriptive-analytical approach involves one-time observation of independent and non-manipulated variables. Hence, the approach reviewed the critical literature on the dimensions of managerial competencies and competitive advantage and compared previous studies with some analysis and comparisons. However, the field approach covered the practical side of this study. It tested the validity of hypotheses and answered its questions while drawing findings from the questionnaire designed for this study, following the practical steps agreed upon.

\subsection{Population of the Study}

The selected respondents were from two pharmaceutical company managers, namely May \& Baker Plc., and Sanofi Avanti, in Lagos State, southwest Nigeria.

\subsection{Sampling Unit}

Managers across all levels of management at the selected pharmaceutical firms were administered copies of the questionnaire in March 2020.

\subsubsection{Sampling Technique}

A stratified and purposive random sampling technique is adopted for this study since the population is divided into subgroups based on their demographic details. Thus, each selected sample is a true representative of its group characteristics, providing the best information to address the purpose of this research.

\subsubsection{Sample Size Determination}

No sample size is adopted here because the whole population is used for sampling.

\subsection{Data Collection}

This study used a primary source of data. The primary data was collated through a structured questionnaire. The study tool was self-developed by referring to several questionnaires used in previous studies related to the subject of study. The questionnaire consists of 4 parts: closeended question, check-list question and seven-point Likert scale where one stands for strongly disagree and 7 for strongly agree. It is imperative to ask closed-end questions because this is effective for market or consumer research.

Adapted from Delvesight, 2018.

\subsection{Operationalisation of Variables}

$$
\begin{aligned}
& \mathrm{Y}=\text { Dependent Variable (Competitive Advantage) } \\
& \quad \mathrm{y}_{1}=\text { Blockbuster products } \\
& \mathrm{X}=\text { Independent Variable (Managerial Competency) }
\end{aligned}
$$


$\mathrm{x}_{1}=$ Shared Vision

$\mathrm{x}_{2}=$ Empowerment

$\mathrm{x}_{3}=$ Cooperation

$\mathrm{Z}=$ Independent Variable (Blockbuster Model)

$\mathrm{z}_{1}=\mathrm{R} \& \mathrm{D}$ driven blockbuster model

$\mathrm{Z}_{2}=$ Customer driven blockbuster model

$\mathrm{Z}_{3}=$ Niche driven blockbuster model

$\mathrm{Z}_{4}=$ Therapeutic driven blockbuster model

$\mathrm{y}_{1}=\mathrm{f}\left(\mathrm{x}_{1}, \mathrm{x}_{2}, \mathrm{x}_{3}\right)+\mathrm{f}\left(\mathrm{z}_{1}, \mathrm{z}_{2}, \mathrm{z}_{3}, \mathrm{z}_{4}\right)$

$\mathrm{y}_{1}=\beta_{0}+\beta_{1} \mathrm{x}_{1}+\beta_{2} \mathrm{x}_{2}+\beta_{3} \mathrm{x}_{3}+\beta_{4} \mathrm{z}_{1}+\beta_{5} \mathrm{z}_{2}+\beta_{6} \mathrm{z}_{3}+\beta_{7} \mathrm{z}_{4}+\mathrm{e}_{1}$

\subsection{Statistical Analysis}

Generally, the idea in statistics is to solve problems using quantitative information. Therefore, descriptive and inferential statistics were used in this study. Descriptive statistics investigated and explored quantitative evidence from the data through each variable's mean and standard deviation and reported any missing value(s). In contrast, inferential statistics investigated the relationship between multivariate variables stating the direction, magnitude and significance of each relationship under review through regression analysis, analysis of variance and path analysis on hypotheses testing.

\subsection{Level of Significance}

0.05 level of significance or $95 \%$ confidence level was used on the statistical inferential tools to justify the findings.

\subsection{Validity and Reliability of the Instrument}

The research instrument was subjected to content and construct validity. The instrument is considered constructive because the Average Variance Extracted (AVE) $>0.708$ was used, an explanation that all the variables are greater than 0.708 or $70.8 \%$. Furthermore, the instrument is considered reliable because the Cronbach's alpha values of its scales were above 0.851 or $85.1 \%$, as presented in Table 3 Moreover, its composite reliability is 0.905 or $90.5 \%$ showing that all the items are reliable.

Table 3 Reliability Statistics

\begin{tabular}{|c|l|l|}
\hline $\begin{array}{c}\text { Cronbach's } \\
\text { Alpha }\end{array}$ & $\begin{array}{l}\text { Cronbach's Alpha } \\
\text { Based } \\
\text { Standardised Items }\end{array}$ & N of Items \\
\hline .851 & .896 & 42 \\
\hline
\end{tabular}

\section{Results and Discussion of Findings}

\subsection{Result and Discussion}

A total of 22 copies of the questionnaire were distributed via e-mail and hand delivery. All of them were retrieved and fit for analysis indicating a response rate of $100 \%$, as presented in Table 4. 
Tabel 4. Response Rate

\begin{tabular}{|l|c|c|c|}
\hline \multicolumn{1}{|c|}{ Response } & Organisation & Frequency & Per cent \\
\hline $\begin{array}{l}\text { Completed usable copies } \\
\text { of a questionnaire by e- } \\
\text { mail }\end{array}$ & May \& Baker & 7 & $31.8 \%$ \\
\hline $\begin{array}{l}\text { Completed usable copies } \\
\text { of a questionnaire by hand } \\
\text { delivery }\end{array}$ & Sanofi Avanti & 15 & $68.2 \%$ \\
\hline Total & 2 & 22 & $100 \%$ \\
\hline
\end{tabular}

The statistics consisting of the demographic details of the respondents are presented in Tables 5 and 6 The arrangements of the respondents in conformity to their gender: $68.2 \%$ of respondents are male. Following their age group: 54.5\% are between 26-39 years old, and $45.5 \%$ are between 45-55 years old. Table 5, showing the arrangements of respondents conformably to outstanding education accomplishments, revealed that the preponderance of the respondents, $59.1 \%$, have earned a master degree, $36.4 \%$ have a bachelor degree, and $4.5 \%$ have a higher diploma. According to the length of service, the distribution of the respondents showed that $54.5 \%$ had spent between 5-10 years in the organisation while $9.1 \%$ have spent more than ten years in service. According to management level, the respondents' distributions showed that $13.6 \%$ are low-level managers, $45.5 \%$ are middle-level managers, and $36.4 \%$ are top-level managers. In comparison, $4.5 \%$ failed to indicate their position on the filled questionnaire.

Table 5 Statistics of Respondents

\begin{tabular}{|c|c|c|c|c|c|c|}
\hline & $\begin{array}{c}\text { Total No of } \\
\text { Managers in } \\
\text { the two } \\
\text { Organisations }\end{array}$ & $\begin{array}{c}\text { Gender of the } \\
\text { Managers }\end{array}$ & $\begin{array}{c}\text { Age of the } \\
\text { managers }\end{array}$ & $\begin{array}{c}\text { Education } \\
\text { Level of } \\
\text { Managers }\end{array}$ & $\begin{array}{c}\text { Length of } \\
\text { service to the } \\
\text { organisation }\end{array}$ & Position \\
\hline $\begin{array}{c}\text { N Valid } \\
\text { Missing }\end{array}$ & 22 & 22 & 22 & 22 & 20 & 21 \\
& 0 & 0 & 0 & 0 & $\mathbf{2}$ & $\mathbf{1}$ \\
\hline
\end{tabular}

Table 6 Demographic Details

\begin{tabular}{|c|c|c|c|c|c|c|c|c|c|c|c|c|c|c|c|}
\hline & \multicolumn{3}{|c|}{ Gender } & \multicolumn{3}{|c|}{ Age } & \multicolumn{4}{|c|}{ Education Level } & \multicolumn{5}{|c|}{ Length of Service } \\
\hline Valid & $\mathbf{M}$ & $\mathbf{F}$ & $\begin{array}{l}\text { Tot } \\
\text { al }\end{array}$ & $\begin{array}{l}26- \\
39 \\
\text { yrs }\end{array}$ & $\begin{array}{l}40- \\
55 \\
\text { yrs }\end{array}$ & $\begin{array}{l}\text { Tot } \\
\text { al }\end{array}$ & $\begin{array}{l}\text { BS } \\
\text { c }\end{array}$ & $\begin{array}{l}\text { Hig } \\
\text { h } \\
\text { Dipl } \\
\text { oma }\end{array}$ & $\begin{array}{l}\text { MS } \\
\text { c }\end{array}$ & $\begin{array}{l}\text { Tot } \\
\text { al }\end{array}$ & $\begin{array}{l}<5 \\
\text { yrs }\end{array}$ & $\begin{array}{l}5- \\
10 \\
\text { yrs }\end{array}$ & $\begin{array}{l}> \\
10 \\
\text { yrs }\end{array}$ & $\begin{array}{l}\text { Missi } \\
\text { ng } \\
\text { Syste } \\
\text { m } \\
\end{array}$ & $\begin{array}{l}\text { Tot } \\
\text { al }\end{array}$ \\
\hline $\begin{array}{l}\text { Frequ } \\
\text { ency }\end{array}$ & 15 & 7 & 22 & 12 & 10 & 22 & 8 & 1 & 13 & 22 & 6 & 12 & 2 & 2 & 22 \\
\hline$\%$ & $\begin{array}{l}68 . \\
2\end{array}$ & $\begin{array}{l}31 . \\
8\end{array}$ & $\begin{array}{l}100 . \\
0\end{array}$ & $\begin{array}{l}54 . \\
5 \\
\end{array}$ & $\begin{array}{l}45 . \\
5\end{array}$ & $\begin{array}{l}100 . \\
0\end{array}$ & $\begin{array}{l}36 . \\
4\end{array}$ & 4.5 & $\begin{array}{l}59 . \\
1 \\
\end{array}$ & $\begin{array}{l}100 . \\
0\end{array}$ & 27.3 & 54.5 & 9.1 & 9.1 & $\begin{array}{l}100 \\
.0\end{array}$ \\
\hline
\end{tabular}

\begin{tabular}{|l|c|l|c|l|c|}
\hline Valid & \multicolumn{4}{|c|}{ Position } & Total \\
\hline & $\begin{array}{l}\text { Top Level } \\
\text { Manager }\end{array}$ & $\begin{array}{l}\text { Middle- } \\
\text { Level } \\
\text { Manager }\end{array}$ & $\begin{array}{l}\text { Low-Level } \\
\text { Manager }\end{array}$ & $\begin{array}{l}\text { Missing } \\
\text { System }\end{array}$ & 1 \\
\hline Frequency & 8 & 10 & 3 & 1 & 22 \\
\hline Per cent & 36.4 & 45.5 & 13.6 & 4.5 & 100 \\
\hline
\end{tabular}




\subsection{Data Treatment}

Before conducting the data analysis, it is necessary to subject the study variables to multivariate diagnostic analysis to test and check for normality, linearity and homoscedasticity assumption of the regression analysis.

\subsubsection{Checking for Missing Value}

The data obtained were first subjected to a statistical frequency test to check for any missing value. The result obtained is presented in table 7

Table 7 Statistics of the Variables

\begin{tabular}{|c|c|c|c|c|c|c|c|c|c|}
\hline & $\begin{array}{l}\text { Shared } \\
\text { Vision }\end{array}$ & $\begin{array}{l}\text { Empower } \\
\text { ment }\end{array}$ & $\begin{array}{l}\text { Cooperati } \\
\text { on }\end{array}$ & $\begin{array}{l}\text { Manageria } \\
1 \\
\text { Competen } \\
\text { cy }\end{array}$ & $\begin{array}{l}\text { Competiti } \\
\text { ve } \\
\text { Advantage }\end{array}$ & $\begin{array}{l}\text { R\&D } \\
\text { Driven } \\
\text { Blockbust } \\
\text { er Model }\end{array}$ & \begin{tabular}{|l} 
Customer \\
Driven \\
Blockbust \\
er Model
\end{tabular} & \begin{tabular}{|l} 
Niche \\
Driven \\
Blockbust \\
er Model
\end{tabular} & $\begin{array}{l}\text { Therapeut } \\
\text { ic } \text { Driven } \\
\text { Blockbust } \\
\text { er } \text { Model }\end{array}$ \\
\hline N Valid & 22 & 22 & 22 & 22 & 22 & 22 & 20 & 22 & 22 \\
\hline Missing & 0 & 0 & 0 & 0 & 0 & 0 & 2 & 0 & 0 \\
\hline
\end{tabular}

Table 7 revealed two missing values on the 'Customer-Driven Blockbuster Model'. Therefore, this variable is treated by the calculation of the mean to replace the missing values. Afterwards, the entire variables are subjected to univariate outliers' test.

\subsubsection{Checking for Outliers}

Table 8 revealed

i. $\quad$ one outlier in a variable: Shared Vision at case number 13 with a value of 4.86 .

ii. one outlier in a variable: Cooperation at case number 13 with a value of 3.38.

iii. one outlier in a variable: Niche Driven Blockbuster Model at case number 22 with value 3.00 .

Table 8 Extreme Values

\begin{tabular}{|l|c|l|c|c|c|c|}
\hline \multirow{2}{*}{} & \multicolumn{2}{|c|}{ Shared Vision } & \multicolumn{2}{c|}{ Cooperation } & \multicolumn{2}{c|}{$\begin{array}{c}\text { Niche Driven Blockbuster } \\
\text { Model }\end{array}$} \\
\cline { 2 - 7 } & Case No & Value & Case No & Value & Case No & Value \\
\hline Highest 1 & 1 & 6.86 & 1 & 7.00 & 1 & 7.00 \\
\hline 2 & 20 & 6.86 & 20 & 7.00 & 5 & 7.00 \\
\hline 3 & 3 & 6.57 & 5 & 6.88 & 10 & 7.00 \\
\hline 4 & 11 & 6.57 & 19 & 6.63 & 11 & 6.67 \\
\hline 5 & 5 & $6.43^{\text {a }}$ & 8 & $6.50^{\text {c }}$ & 12 & $6.67^{\mathrm{h}}$ \\
\hline Lowest 1 & $\mathbf{1 3}$ & $\mathbf{4 . 8 6}$ & $\mathbf{1 3}$ & $\mathbf{3 . 3 8}$ & $\mathbf{2 2}$ & $\mathbf{3 . 0 0}$ \\
\hline 2 & 4 & 5.57 & 21 & 5.38 & 9 & 4.00 \\
\hline 3 & 19 & 5.71 & 16 & 5.38 & 17 & 5.00 \\
\hline 4 & 15 & 5.71 & 15 & 5.50 & 14 & 5.00 \\
\hline 5 & 10 & 5.71 & 18 & 5.63 & 6 & 5.00 \\
\hline
\end{tabular}

The listed cases were deleted, and their values replaced by the calculation of the mean. Afterwards, the identified variables were transformed by taking their square roots. 


\subsubsection{Checking for Univariate Normality}

Based on the result of the univariate normality test, the following variables: Managerial Competency, Competitive Advantage, R \& D Driven Blockbuster Model, Customer-Driven Blockbuster Model, and Therapeutic-Driven Blockbuster Model have negative skewness and kurtosis values closer to zero, indicating normal distributions while the other variables: Shared vision, Empowerment, Cooperation and Niche-Driven Blockbuster Model, although possess negative skewness that is closer to zero, instead, they have positive kurtosis ranging from +1 to +7 . However, the Q-Q plots for all the variables showed a normal distribution, with most of the data falling close to the straight lines.

Table 9 presented the results of their Kolmogorov-Smirnov (K-S) tests at $\alpha=0.05$ with a critical value of 0.264 , indicating that the null hypothesis is accepted for all the variables. This confirms the normality of the distributions.

Table 9 Summary of Univariate Normality Test

\begin{tabular}{|c|c|c|c|c|c|c|c|c|c|}
\hline \multicolumn{7}{|l|}{ Statistics } & \multicolumn{2}{|c|}{$\begin{array}{l}\text { Kolmogorov- } \\
\text { Smirnov test }\end{array}$} & \multirow{2}{*}{$\begin{array}{l}\alpha=.05 \\
(0.264) \\
\mathrm{H}_{\mathrm{o}}\end{array}$} \\
\hline Variable & $\begin{array}{l}\mathrm{N} \\
\text { Valid }\end{array}$ & $\begin{array}{l}\text { Missi } \\
\text { ng }\end{array}$ & Mean & $\begin{array}{l}\text { Std. } \\
\text { Dev }\end{array}$ & $\begin{array}{l}\text { Skewne } \\
\text { ss }\end{array}$ & $\begin{array}{l}\text { Kurtosi } \\
\mathrm{s}\end{array}$ & $\begin{array}{l}\text { K-S } \\
\text { Value }\end{array}$ & Sig & \\
\hline $\begin{array}{l}\text { Competitive } \\
\text { Advantage }\end{array}$ & 22 & 0 & 6.250 & 0.632 & -0.468 & -0.507 & 0.164 & 0.126 & Accepted \\
\hline Empowerment & 22 & 0 & 6.305 & 0.480 & -0.778 & -0.210 & 0.165 & 0.122 & Accepted \\
\hline Shared Vision & 22 & 0 & 2.476 & 0.076 & 0.267 & -0.615 & 0.124 & 0.200 & Accepted \\
\hline Cooperation & 22 & 0 & 2.468 & 0.102 & 0.195 & -0.738 & 0.111 & 0.200 & Accepted \\
\hline $\begin{array}{l}\text { R\&D Driven } \\
\text { Blockbuster } \\
\text { Model }\end{array}$ & 22 & 0 & 6.046 & 0.928 & -0.869 & -0.012 & 0.160 & 0.15 & Accepted \\
\hline $\begin{array}{l}\text { Customer } \\
\text { Driven } \\
\text { Blockbuster } \\
\text { Model }\end{array}$ & 22 & 0 & 5.876 & 0.590 & -0.242 & -0.210 & 0.139 & 0.200 & Accepted \\
\hline $\begin{array}{l}\text { Therapeutic } \\
\text { Driven } \\
\text { Blockbuster } \\
\text { Model }\end{array}$ & 22 & 0 & 6.091 & 0.75 & -0.340 & -0.697 & 0.160 & 0.122 & Accepted \\
\hline $\begin{array}{l}\text { Niche Driven } \\
\text { Blockbuster } \\
\text { Model }\end{array}$ & 22 & 0 & 2.405 & 0.192 & -0.631 & -0.150 & 0.141 & 0.200 & Accepted \\
\hline $\begin{array}{l}\text { Managerial } \\
\text { Competency }\end{array}$ & 22 & 0 & 5.455 & 0.809 & -0.257 & -0.856 & 0.113 & 0.200 & Accepted \\
\hline
\end{tabular}




\subsubsection{Checking for Multivariate Outlier}

The result of the multivariate outlier revealed no outlier on all the listed variables. Moreover, there are no extreme values on the Mahalanobis distance. Hence no value on the MAH_1 exceeded critical $\chi 2(46.8)$ at $\mathrm{p}<0.001$.

\subsubsection{Checking for Multivariate Linearity}

The residual plot displayed an approximately rectangular shape with few scattered plots, while the scatterplot matrix displayed some elliptical shapes of the independent variables. Hence, one can conclude that the assumptions of normality, linearity and homoscedasticity are met for these variables.

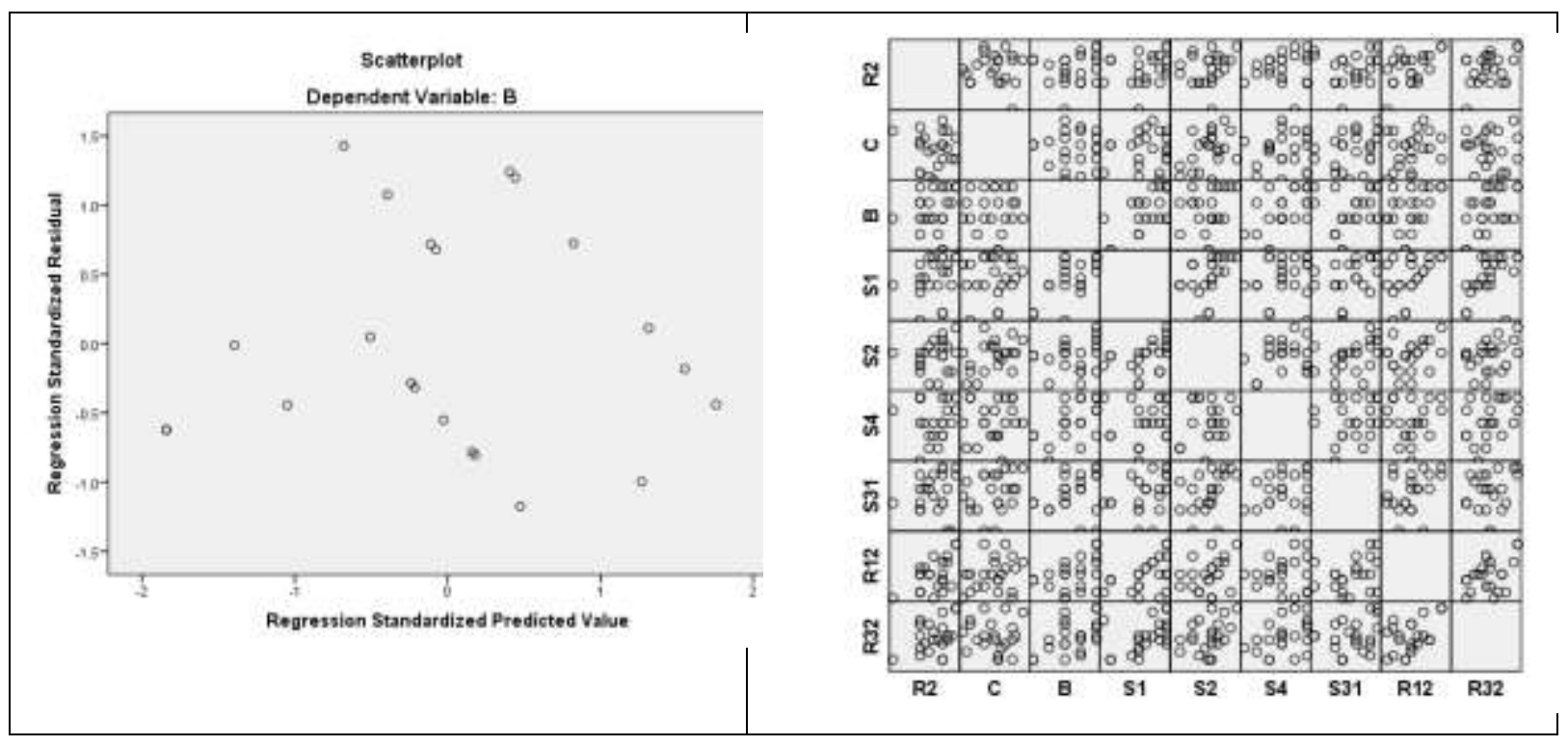

Fig. $2 \mathrm{~B}=$ Competitive advantage

\subsubsection{Regression Analysis}

Table 10 showed the model summary of the regression analysis testing the relationship between blockbuster models and competitive advantage. The result showed a strong positive correlation between blockbuster models and competitive advantage with an R-value of 0.810 . However, the result also indicated that only $65.6 \%$ of the blockbuster models affected competitive advantage.

Table 10 Model Summary ${ }^{\mathrm{b}} 1$

\begin{tabular}{|l|l|l|l|l|}
\hline Model & $\mathrm{R}$ & R Square & $\begin{array}{l}\text { Adjusted Rquare } \\
\text { Square }\end{array}$ & $\begin{array}{l}\text { Std. Error of } \\
\text { the Estimate }\end{array}$ \\
\hline 1 & $.810^{\mathrm{a}}$ & .656 & .575 & .41184 \\
\hline
\end{tabular}

a. Predictors: (Constant), R \& D, Customer, Niche and

Therapeutic Driven Blockbuster Models

b. Dependent Variable: Competitive Advantage

Table 11 . The second model summary displayed a strong positive correlation $(0.845)$ between the dependent and independent variables. The value of the coefficient of determination revealed a $71.4 \%$ causal effect on the dependent variable. 
Table 11 Model Summary ${ }^{\mathrm{b}} 2$

\begin{tabular}{|l|l|l|l|l|}
\hline Model & \multicolumn{1}{|c|}{$\mathrm{R}$} & \multicolumn{1}{|c|}{ R Square } & Adjusted R Square & Std. Error of the Estimate \\
\hline 1 & $.845^{\mathrm{a}}$ & .714 & .539 & .42887 \\
\hline
\end{tabular}

a. Predictors: (Constant), Managerial competency' dimensions and Blockbuster Models

b. Dependent Variable: Competitive Advantage

Table 12 of the model summary 3 revealed an R-value of 0.370 , indicating a weak positive correlation between shared vision, empowerment, cooperation and managerial competency of the selected firms.

Table 12 Model Summary 3

\begin{tabular}{|l|l|l|l|l|}
\hline Model & \multicolumn{1}{|c|}{$\mathrm{R}$} & R Square & Adjusted R Square & Std. Error of the Estimate \\
\hline 1 & $.370^{\mathrm{a}}$ & .137 & -.007 & .81161 \\
\hline
\end{tabular}

a. Predictors: (Constant), Shared Vision, Empowerment and Cooperation

b. Dependent Variable: Managerial Competency

\subsubsection{Path Analysis}

Table 12 revealed a B weight of 3.286, indicating a positive change in the dependent variable (Managerial competency) when the independent variables (shared vision, empowerment and cooperation) increase by 1 . However, the beta, $\beta$ value of 0.453 for the variable shared vision indicates a significant relationship with the dependent variable above the two other predictors of managerial competencies for the selected pharmaceutical firms.

Table 12

Coefficients ${ }^{\mathrm{a}}$ Table 1 for Variables

\begin{tabular}{|c|c|c|c|c|c|c|}
\hline \multirow{2}{*}{\multicolumn{2}{|c|}{ Model }} & \multicolumn{2}{|c|}{$\begin{array}{l}\text { Unstandardised } \\
\text { Coefficients }\end{array}$} & \multirow{2}{*}{\begin{tabular}{|l|}
$\begin{array}{l}\text { Standardised } \\
\text { Coefficients }\end{array}$ \\
Beta \\
\end{tabular}} & \multirow[b]{2}{*}{ t } & \multirow[b]{2}{*}{ Sig. } \\
\hline & & B & Std. Error & & & \\
\hline \multirow[t]{4}{*}{1} & (Constant) & 3.286 & 3.119 & & 1.053 & .306 \\
\hline & Empowerment & -.282 & .445 & -.167 & -.634 & .534 \\
\hline & Shared Vision & .970 & .583 & .453 & 1.663 & .114 \\
\hline & Cooperation & -.328 & .408 & -.204 & -.804 & .432 \\
\hline
\end{tabular}

a. Dependent Variable: Managerial competencies

Table 13 revealed a $\mathrm{B}$ weight of -1.966 , an indication that there is a negative change in the dependent variable (Competitive advantage) when the independent variables increase by a factor of 1 . However, this marked difference is overcome by the potential weights of the beta $(\beta)$ values of five of the independent variables: managerial competency $[\beta=-0.175, t(13)=-$ 0.934, $\mathrm{p}=0.367]$; empowerment $[\beta=-0.136, \mathrm{t}(13)=-0.744, \mathrm{p}=0.470]$; shared vision $[\beta=$ $0.308, \mathrm{t}(13)=1.452, \mathrm{p}=0.170] ; \mathrm{R} \& \mathrm{D}$ driven blockbuster model $[\beta=0.523, \mathrm{t}(13)=2.676, \mathrm{p}$ $=0.019]$ and therapeutic driven blockbuster model $[\beta=0.522, t(13)=3.060, p=0.009]$ 
significantly contributed to the model. Hence, the regression equation for the standardized Beta is thus written as

Competitive Advantage $=1.452 \mathrm{Z}_{\text {shared vision }}+2.676 \mathrm{Z}_{\mathrm{R} \& \mathrm{D} \text { Blockbuster }}+3.060 \mathrm{Z}_{\text {therapeutic blockbuster }}$ - $0.934 \mathrm{Z}_{\text {managerial competency }}-0.744 \mathrm{Z}_{\mathrm{empowerment}}$

Table 13

Coefficients $^{\mathrm{a}}$

\begin{tabular}{|c|c|c|c|c|c|c|c|c|c|}
\hline \multirow[b]{2}{*}{ Model } & \multicolumn{2}{|c|}{$\begin{array}{l}\text { Unstandardised } \\
\text { Coefficients }\end{array}$} & \multirow{2}{*}{$\begin{array}{r}\text { tandardised } \\
\text { Coefficients } \\
\text { Beta } \\
\end{array}$} & \multirow[b]{2}{*}{$\mathrm{t}$} & \multirow[b]{2}{*}{ Sig. } & \multicolumn{2}{|c|}{$\begin{array}{l}\text { Collinearity } \\
\text { Statistics }\end{array}$} & \multicolumn{2}{|c|}{ Correlations } \\
\hline & $\mathrm{B}$ & $\begin{array}{l}\text { Std. } \\
\text { Error }\end{array}$ & & & & Tolerance & VIF & Partial & Part \\
\hline 1 (Constant) & -1.966 & 3.629 & & -.542 & .597 & & & & \\
\hline Empowerment & -.179 & .240 & -.136 & -.744 & .470 & .661 & 1.512 & .202 & -.110 \\
\hline Managerial & & & & & & & & & \\
\hline Competency & -.136 & .146 & -.175 & -.934 & .367 & .628 & 1.593 & -.251 & -.138 \\
\hline $\begin{array}{l}\mathrm{R} \& \mathrm{D} \text { Driven BB } \\
\text { Model }\end{array}$ & .356 & .133 & .523 & 2.676 & .019 & .575 & 1.739 & .596 & 397 \\
\hline Customer-Driven & & & & & & & & & \\
\hline BB Model & -.059 & .207 & -.055 & -.286 & .779 & .588 & 1.701 & -.079 & 042 \\
\hline $\begin{array}{l}\text { Therapeutic Driven } \\
\text { BB Model }\end{array}$ & .440 & .144 & .522 & 3.060 & .009 & .754 & 1.327 & .047 & 454 \\
\hline Niche-Driven BB & & & & & & & & & \\
\hline Model & -.263 & .577 & -.080 & -.456 & .656 & .716 & 1.396 & .126 & 068 \\
\hline Shared Vision & 2.556 & 1.761 & .308 & 1.452 & .170 & .489 & 2.046 & 373 & 215 \\
\hline Cooperation & -.038 & 1.337 & -.006 & -.028 & .978 & .474 & 2.108 & -.008 & .004 \\
\hline
\end{tabular}

a. Dependent Variable: Competitive advantage

Table 14 revealed a B weight of 2.097, indicating a positive change in the dependent variable (competitive advantage) when the independent variables increase by a factor of 1 . However, the beta, $\beta$ values of 0.634 and 0.484 for the variables $\mathrm{R} \& \mathrm{D}$ and therapeutic driven blockbuster models respectively indicates a significant relationship with the dependent variable above the two other predictors of competitive advantage of the selected pharmaceutical firms.

Table 14 Coefficients ${ }^{\mathrm{a}}$

\begin{tabular}{|c|c|c|c|c|c|c|}
\hline \multirow{2}{*}{\multicolumn{2}{|c|}{ Model }} & \multicolumn{2}{|c|}{ Unstandardised Coefficients } & \multirow{2}{*}{\begin{tabular}{|l} 
Standardised \\
Coefficients \\
Beta \\
\end{tabular}} & & \multirow[b]{2}{*}{ Sig. } \\
\hline & & $\mathrm{B}$ & Std. Error & & & \\
\hline \multirow[t]{5}{*}{1} & (Constant) & 2.097 & 1.079 & & 1.943 & .069 \\
\hline & $\mathrm{R} \& \mathrm{D}$ model & .431 & .113 & .634 & 3.812 & .001 \\
\hline & Customer-Driven & -.122 & .179 & -.114 & -.684 & .503 \\
\hline & Therapeutic Model & .407 & .124 & .484 & 3.294 & .004 \\
\hline & Niche-Driven & -.038 & .117 & -.054 & -.323 & .751 \\
\hline
\end{tabular}

a. Dependent Variable: Competitive advantage 


\subsubsection{Factorial Analysis of Variance}

ANOVA summary indicate that the overall model of the eight independent variables significantly predicts competitive advantage $\left[R=0.845, R^{2}=0.714, R^{2}\right.$ adj $=0.539, F(8,13)=$ 4.067, $\mathrm{p}<0.05]$ Hence, the null hypothesis is accepted at $\mathrm{p}<0.05$.

\subsection{Discussion of Findings}

Table 15 ANOVA $^{\mathrm{a}}$

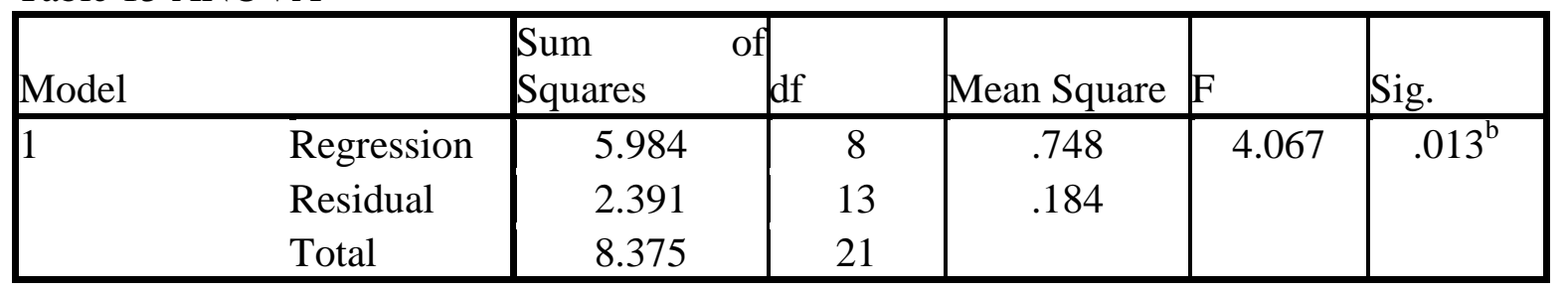

a. Dependent Variable: Competitive Advantage

b. Predictors: (Constant), Managerial competency dimensions and Blockbuster models

From the result presented in Table 12, it is gathered that there exists a statistically significant relationship between blockbuster models and the competitive advantage of the selected pharmaceutical firms. This aligns with the study of (Campbell, 2007) beyond the blockbuster: finding the next profit zone in pharmaceuticals. The result is also in harmony with the report of Song \& Han (2016) on exploring strategic design possibilities in the pharmaceutical industry.

From the result presented in Table 13, it can be deduced that it is statistically significant on the impact of dimensions of managerial competency and blockbuster models on competitive advantage. Therefore, this answers the research question on the impact of dimensions of managerial competency and blockbuster models on competitive advantage in the pharmaceutical industry in Lagos State. Furthermore, the answer given conforms with the empirical review of Suarez et al. (2018) in their study on the impact of managerial competencies on organisational culture.

The result presented in Table 14 showed that there exists a main statistical effect between shared vision and managerial competency. This answers the research question on the correlation between the selected pharmaceutical firms' shared vision and managerial competency. The finding confirms the empirical review of Ochonma et al. (2018 in their study on managerial competency among hospital managers. However, Table 16 showed no statistically significant relationship between dimensions of managerial competency: cooperation and empowerment and managerial competency of the selected pharmaceutical industry. The finding is contrary to the empirical review of (Agahet al., 2012) in their study on the effect of core competence on competitive advantage.

Table16 Summary of the hypotheses

\begin{tabular}{|l|l|l|l|}
\hline $\mathrm{H}_{\mathrm{o}}$ & Hypothesis & Model & Decision \\
\hline $\mathrm{H}_{\mathrm{o}} 1$ & $\begin{array}{l}\text { Blockbuster models have a significant impact on the } \\
\text { competitive advantage of the selected pharmaceutical } \\
\text { firms. }\end{array}$ & $\mathrm{R}^{2}=0.656$ & Accept \\
\hline
\end{tabular}




\begin{tabular}{|l|l|l|l|}
\hline $\mathrm{H}_{\mathrm{o}} 2$ & $\begin{array}{l}\text { Managerial competency' dimensions and blockbuster } \\
\text { models have a significant impact on the managerial } \\
\text { competency of the selected pharmaceutical firms. }\end{array}$ & $\mathrm{R}^{2}=0.714$ & Accept \\
\hline $\mathrm{H}_{\mathrm{o}} 3$ & $\begin{array}{l}\text { Managerial competency' dimensions have a significant } \\
\text { impact on the managerial competency of the selected } \\
\text { pharmaceutical firms. }\end{array}$ & $\mathrm{R}^{2}=0.137$ & Reject \\
\hline $\mathrm{H}_{0} 4$ & $\begin{array}{l}\text { Shared vision, empowerment and cooperation have a } \\
\text { significant correlation with the managerial competency } \\
\text { of the selected pharmaceutical firms. }\end{array}$ & $\mathrm{R}=0.370$ & Accept \\
\hline
\end{tabular}

\section{Conclusion}

Drawing from the result presented in the data analyses, three out of the four hypotheses were accepted at a specified significance level, showing that managerial competencies and blockbuster models significantly impact competitive advantage. Moreover, all the statistical tests performed on the sample confirmed a strong relationship between managerial competencies and competitive advantage on the one hand and blockbuster models and competitive advantage on the other hand. This established that most respondents, which are managers across all levels, have the requisite knowledge to transform their firms through appropriate business designs in generating pharmaceutical blockbuster products, thus securing a sustainable competitive advantage.

Managerial competencies are unique resources: knowledge, skills, and abilities embedded in a manager, which upon utilisation enables him to direct a firm's operation successfully. This nature developed blockbuster models through appropriate business design, including business logic and value capturing approach leading to firm's efficiency in generating large market share and significant revenue - a competitive advantage.

Certainly, the result obtained from the data indicated that most respondents understood the usefulness of shared vision - a component of managerial competencies. However, there is a dearth of understanding of what cooperation and empowerment meant for these firms to gain sustainable competitive advantage. Moreover, the findings also revealed that only R \& D and therapeutic driven blockbuster models are currently being used by the managers of the selected pharmaceutical firms in their business operations, an indication that their blockbuster models are not adequately explored, this will certainly reflect in their annual return on sales and assets at the end of a fiscal year. Therefore, they need to fully harness their resources in this area to dominate the industry due to a growing competition that described the Nigerian pharmaceutical markets.

Deep knowledge of managerial competencies and blockbuster models are highly needed in the selected pharmaceutical companies to gain business expansion, maintain low average costs, and achieve significant market share while improving their service delivery and capacity to support groups or teams through training coaching sharing specialist knowledge.

The significant contribution of this study is the development of a conceptual framework depicting the relationship between managerial competencies, blockbuster models and competitive advantage. Adopting this model would guide strategies in developing business designs that could create blockbuster drugs leading to sustainable competitive advantage in the pharmaceutical industry. In addition, this study added to the existing body of knowledge the exceptional uniqueness of managerial competencies in guiding strategies to provide 
potential access to a wide variety of markets through blockbuster models, which upon implementation will see many Nigerian pharmaceutical companies achieving significant market share, employ more employees to dominate the markets, and improve customer benefits by extending the life expectancy of patients with chronic health conditions through blockbuster drugs.

Managerial competency, which is peculiar of a good manager for an organisation's sustained success, should be a conscious effort on any firm in a recruitment process; it is not a thing to be left to chance. Moreover, this study recommends deploying blockbuster models across all industries for a distinctive advantage ineffective organisation performance and greater productivity. Finally, this study also recommends the development of strategy in this respect toward achieving sustainable competitive advantage.

Furthermore, the research recommends a cooperative attempt among individual employees to perform arduous tasks in offering unique product services while utilising product innovation and new product design in an environment of employees' activeness with individuals working together as partners upholding the company's values.

\section{References}

Agah, S., Alrubaiee, L., \& Jamhour, M. (2012). Effect of core competence on competitive advantage and organisational performance. International Journal of Business and Management, 7(1), 192-204.

Amit, R., \& Schoemaker, P. (1993). Strategic assets and organisational rent. Strategic Management Journal, 14(1), 33-46.

Ansoff, H. (1965). Corporate strategy: An analytic approach to business policy for growth and expansion, New York: McGraw Hill.

Asada, K. (2016). Drugmakers seek ways to deal with the "patent cliff": Biotechnology. Nikkel Asian Review. [Online] Available: googleweblight.com/i?u=https://asia.nickel.com/Business/Biotechnology/Drugmakers-seekways-to-deal-with-the-patent-cliff\&hl=en-NG

Barney, J. B. (1991). Firm resources and sustained competitive advantage. Journal of Management, 17(1), 99-120.

Berger, L. A., \& Berger, D. R. (2004). The talent management handbook. McGraw-Hill.

Boyatzis, R. E., Goleman, D., \& Acquisition, H. (2007). Emotional and social competency inventory.

Campbell, D., Chadwick-Jones, A., Pasternak, A., Sabow, A., Weissel, M., \& Hall, J. (2007). Beyond the blockbuster: Finding the next profit zone in pharmaceuticals through business design thinking. America: Marsh \& McLennan Companies. [Online] Available: www.oliverwyman.com

Carroll, S. (2009, June 6). Goodbye blockbuster medicines: Hello, new pharmaceutical business models. The Pharmaceutical Journal, 282, 681-682. [Online] Available: www.pjonline.com

Chandler, A. (1962). Strategy and structure. Cambridge: MIT Press. 
Crook, T. R., Ketchen, D. J., Combs, J. G., \& Todd, S. Y. (2008). Strategic resource and performance: a meta-analysis. Strategic Management Journal, 29(11), 1141-1154.

Croteau, A.-M., Solomon, S., Raymond, L., \& Bergeron, F. (2001). Organisational and technological infrastructures alignment. Annual Hawaii International Conference on System Sciences (HICSS-34), 8, p. 8049.

DelveInsight. (2017). 5 potential blockbusterdrugs to watch in 2017-2018. DelveInsight. [Online] Available: htpps//blog.marketresearch.com/5-potential-blockbuster-drug5-to-watchin-2017-2018. November 1, 2017.

DelveInsight. (2019). 4 top New drugs that will make their mark in the coming years. DelveInsight. [Online] Available: https//blog.marketresearch.com/4-top-new-drugs-that-willmake-their-mark-in-the-coming-years. November 6, 2019

Denoon, A., \& Vollebregt, E. (2010). Can regenerative medicine save big pharma's business model from the patent cliff? Journal of Regen Medicine, 5, 687-690.

Dolfsma, W. (2011). Patent strategising. Journal of Intellect Capital, 12, 168-178.

Dolgin, E. (2010). Big pharma moves from 'blockbusters' to 'niche busters'-Natural Medicine, 16, p. 837.

Ekpudu, J. E., Okafor, L. I., \& Ogege, S. (2010). Business and its stakeholders, expectations, responsibilities and stability in the Nigerian business environment. Journal of Business Administration and Management, 5(3).

Esfandiari, K. H., \& Yousefi, P. (2011). Threats and opportunities for the drugs economy. Annual Iranian Conference of Pharmaceutical and Treatment Economics., (p. 19). Tehran. [Online] Available: www.lpte90.cnf.ir/files_site/paperlist/r_12-120416074804.pdf

Evans, J. R. (2003). Business analytics: methods models, and decision. In Forthcoming. Prentice-Hall.

Grove, A. S. (1983). Dimensions of competitive analysis. In Summary of high output management (Vol. 13, p. 978).

Gyurjyan, G., Parsons, I., \& Thaker, S. (2014). Overcoming change fatigue in the pharmaceutical industry: A health check for pharma. VME.

Hafeez, K., \& Essmail, E. A. (2007). Evaluating organisation core competencies and associated personal competencies using analytical hierarchy process. Management Research News, 30(8), 530-547. doi:http://dx.doi.org/10.1108/014909170710773689

Hafeez, K., Zhang, Y., \& Malak, N. (2002). Core competence for sustainable competitive advantage: a structured methodology for identifying core competence. IEEE transactions on engineering management, 49(1), 28-35. doi:http://dx.doi.org/10.1109/17.985745

Hamel, G., \& Prahalad, C. (1994). The concept of core competence. In G. Hamel, \& A. Heene. New York, Wiley.

Hamzat, B. S., \& Ifekwem, N. (2013). How enterprises from the developing economies can internationalise their value chains. International Journal of Economics and Management Sciences, 2(8), 14-24.

Hollis, A. (2002). The importance of being first: Evidence from Canadian generic pharmaceuticals. Health Economics, 11, 723-724. 
Hooley, G., Gox, T., Shipley, D., Fah, J., Breaks, J., \& Kilos, K. (1996). 'Foreign direct investment in Hungary: Resource acquisition and domestic competitive advantage. Journal of International Business Studies, 27(4), 683-709.

Hoskisson, R. E., Hitt, M. A., Wan, W. P., \& Yiu, D. (1999). 'Theory and research in strategic management: Swings of a pendulum. Journal of Management, 25(3), 417-456.

Ismail, A. I., Rose, R. C., Abdullah, H., \& Uli, J. I. (2010). The relationship between organisational competitive advantage and performance moderated by the age and size of firms. Asian Academy of Management Journal, 15, 157-173.

Kamukama, N., Kyomuhangi, D. S., Akisimire, R., \& Orobia, L. A. (2016). Competitive advantage: Mediator of managerial competence and financial performance of commercial banks in Uganda. African Journal of Economic and Management Studies, 8(2), 221-234. doi:https://doi.org/10.1108/AJEMS-10-2016-0142

King, A. W., \& Zeithamul, C. P. (2001). Managing organisational competencies for competitive advantage: The middle management edge. The Academy of Management Executive, 15, 95-106.

Maier, R., \& Remus, U. (2002). Defining process-oriented knowledge management strategies. Knowledge and Process Management, 9(22), 103-118.

Markhloufi, L., \& Al-Erjal, H. M. (2017). The effect of core competence on the sustainable competitive advantage of Malaysian SMEs furniture industry. Journal of Humanities, Language, Culture and Business (HLCB), 1(3), 90-99. [Online] Available: www.icohlcb.com

Markides, C., \& Williamson, P. J. (1994). Related diversification, core competencies and corporate performance. Strategic Management Journal, 15, 149-165.

Markovic, M., Draskovic, N., \& Samardzija, J. (2017). Competitive advantage in the costsensitive glass packaging industry through outbound logistics. 17th international Scientific Conference Business Logistics in Modern Management, 281-292. Osijek, Croatia.

Mintberg, H., Quinn, J. B., \& Ghoshal, S. (1998). The strategy process: Concepts, contexts, and cases (3rd ed.). USA: Prentice-Hall.

Morton, F. S., \& Boller, L. T. (2017). Enabling competition in pharmaceutical markets. Hutchins Center for Health, Fiscal and Monetary Policy, 1-53.

Mousavi, S. Z., Rasekhi, S., Golestani, M., \& Imani, A. (2018). Studying international competitiveness in pharmaceutical sector in selected developed countries. Semantic Scholar, 11(3). doi:10.22159/ajpcr.2018.v11i3.21554

Murray, P. (2000). Designing for business benefits from knowledge management. In C. Despres, \& D. Chauvel, Knowledge horizons: The present and the promise of knowledge management (eds ed., pp. 171-194). Boston: Butterworth-Heinemann.

Ochonma, O. G., Nwankwor, C. A., Henry-Arize, I., Igwe, S. E., Nwodoh, C. O., \& Ingwu, J. A. (2018). Managerial competency among hospital managers: Does experience on the job matter? International Journal of Social Sciences and Management Research, 4(3). [Online] Available: www.iiardpub.org

Okafor, L. I., Olafenwa, A. T., \& Ifekwrem, N. E. (2019). An advantage in Nigerian pharmaceutical industry. African Research Review: An international multidisciplinary journal, 13(4), 123-135. doi:http://dx.doi.org/10.4314/afrrev.v13i4.11 
Papp, R., \& Lufmann, J. (1995). 'Business and IT Strategic alignment: New perspectives and assessments in the association for information systems. Inaugural Americas conference on information systems. Pittsburgh.

Penrose, E. T. (1959). The Theory of the Growth of the Firm. New York: John Wiley

Peteraf, M. A., \& Barney, J. B. (2003). Unveiling the resource-based tangle. Managerial and Decision Economics, 24(4), 309-323.

Peteraf, M. A., \& Bergen, M. E. (2003). Scanning dynamic competitive landscapes: A market-based and resource-based framework. Strategic Management Journal, 24(1), 10271041.

Porter, M. E. (1979). How competitive forces shape strategy. Havard Business Review, 57(2), 137-146.

Porter, M. E. (1980). Competitive strategy: Techniques for analysing industries and competitors. New York: Free Press.

Prahalad, C. K., \& Hamel, G. (1994). Strategy as a field of study: Why search for a new paradigm? Strategic Management Journal, 15, 5-16.

Raasch, C. (2008). Launching a fighter brand to cushion patent expiry: The case of Zocor. Journal of Medicine Mark, 8, 119-126.

Rijamampianina, R., Abratt, R., \& February, Y. (2003). A framework for concentric diversification through sustainable competitive advantage. Management Decision, 41(4), 362-371.

Sadler, P. (2003). Strategic Management (2nd ed.). Kogan page limited.

Sanchez, R. (2004). Understanding competence-based management: identifying and managing five modes of competence. Journal of Business Research, 57(5), 518-532.

Santos-Vijande, M. L., Sanzo-Perez, M. J., Alvarez-Gonzalez, L. I., \& Vazquez-Casielles, R. (2005). Organisational learning and market orientation: Interface and effects on performance. $\begin{array}{llll}\text { Industrial Marketing } \quad \text { Management, } & \text { 187-202. }\end{array}$ doi:http://dx.doi.org/10.1016/j.indmarman.2004.08.004

Song, C. H., \& Han, J. (2016). Patent cliff and strategic switch: Exploring strategic design possibilities in the pharmaceutical industry. Springer Plus, 5, 692. doi:https://doi.org/10.1186/s40064-016-2323-1

Steyn, Z., \& Van Staden, L. J. (2018). Investigating selected self-management competencies of managers. Acta Commercii, 18(1), 530. doi:https://doi.org/10.4102/acv18i1.530

Suarez, M., Martelo, R. J., \& Franco, D. (2018). The influence of managerial competencies in the organisational culture of public university institutes. Contemporary Engineering Sciences, 11(32), 1579-1589. [Online] Available: www.mhikari.com

Teece, D. J. (2010). Business models, business strategy and innovation. Long-Range Plan, 43, 172-194.

Teece, D. J., Pisano, G., \& Shuen, A. (1997). Dynamic capabilities and strategic management. Strategic Management Journal, 18(7), 509-533.

Tehseen, S., \& Ramayah, T. (2015). Entrepreneurial competencies and SMEs business success: The contingent role of external integration. Mediterranean Journal of Social Sciences, 6(1). 
Tiwana, A. (2002). The knowledge management toolkit: Orchestrating IT, strategy, and knowledge platforms. Upper Saddle River: Prentice-Hall.

Turtle, E., Parece, A., \& Hector, A. (2004). Beyond lifecycle management- optimising performance following patent expiry. [Online] Available: analysisgroup.com: www.analysisgroup.com/uploadedfiles/content/insights/publishing/patent_expiry.pdf 0ctober 2,2015

Usshawanitchakit, P. (2008). Impacts of organisational learning on innovation orientation and firm efficiency: An empirical assessment of accounting firms in Thailand. International Journal of Business Research, 8(4).

Veliu, I. L., \& Manxhari, M. (2017). The impact of managerial competencies on business performance of SMEs in Kosovo. Vadyba Journal of Management, 30(1).

Wang, H. L. (2004). A framework to support and understand strategic decision-making in business-to-business electronic commerce. The International Workshop on Business and Information.

Wang, H. L. (2014). Theories for competitive advantage. In H. Hassan, Being practical with theory: A window into Business Research (pp. 33-43). Wollongong, Australia: Theory.

Wirda, F., Elfrindri, H., \& Rivai, H. A. (2019). Competitive advantage: Mediation effect between entrepreneurial competency and business performance in creative industries in West Sumatera Indonesia. Academy of Entrepreneurship Journal, 25(1).

Zhang, X., \& Bartol, K. M. (2010). Linking empowering leadership and employee creativity: The influence of psychological empowerment intrinsic motivation, and creative process engagement. The Academy of Management Journal, 53(1), 107-128.

\section{Copyrights}

Copyright for this article is retained by the author(s), with first publication rights granted to the journal.

This is an open-access article distributed under the terms and conditions of the Creative Commons Attribution license (http://creativecommons.org/licenses/by/4.0/). 